Ilja van den Broek

\title{
DE PERSOONLIJKE POLITIEK VAN NEW JOURNALISM
}

Het Nederlandse literaire tijdschrift Pafionate besteedde eind 2002 een special aan New Journalism. Redacteuren en medewerkers schreven (historische) beschouwingen en trachtten technieken van toen opnieuw in de praktijk te brengen. John Schoorl beschreef zijn gedachten, gevoelens en fantasieën in de uren dat hij wachtte op een geheime en wellicht fictieve ontmoeting met een sleutelfiguur in de bouwfraude-zaak. Alex Boogers begroef zich enkele maanden en daarna vijftien pagina's lang in de Amsterdamse Thaiboks-onderwereld. Zijn belevenissen en die van zijn hoofdpersonen lezen als een film: dialogen en scènes ontrollen zich op het papier. ' Ook in de Verenigde Staten, waar New Journalism ontstond, spreekt deze journalistieke stroming nog tot de verbeelding. Zij beleeft volgens de American Journalism Review een heropleving als 'literary journalism': vertellende journalistiek, die gebruik maakt van dialogen, scènes en betekenisvolle details. Amerikaanse universiteiten bieden 'creative nonfiction' Master's aan, en literaire journalisten krijgen belangrijke prijzen. ${ }^{2}$

New Journalism wordt meestal omschreven als een vorm van journalistiek die gebruikt maakt van literaire technieken, of als literaire nonfictie. Sinds het einde van de jaren zeventig en zeker vanaf het begin van de jaren tachtig behandelde de Amerikaanse literatuur over deze stroming vooral de 'nonfiction novels' van Tom Wolfe, Hunter S. Thompson, Gay Talese, Norman Mailer en Truman Capote. De reportages die de meeste van deze auteurs in eerste instantie schreven, Wolfe bijvoorbeeld voor Esquire en voor de zaterdagbijlage van de New York Herald Tribune, kregen minder aandacht. In eerdere (contemporaine) analyses van het fenomeen door wetenschappers, uitgevers en de 'nieuwe journalisten' zelf, stonden juist de reportages centraal, en werd met 'nieuwe journalistiek' ook de nieuwe werkwijze van de zogenaamde 'underground press' aangeduid. Deze wilde een alternatief bieden voor de gevestigde kranten, die als spreekbuis van de overheid officiële informatie zouden geven, en door hun uitgevers werden gedwongen commerciële belangen voorop te stellen. De alternatieve pers wilde een 'ander' wereldbeeld tonen, en met de mantel der 'autoriteit' bedekte misstanden opsporen en aan de kaak stellen. 


\section{Cultuurkritiek}

In I994 vestigde de Nederlandse literatuurwetenschapper José van Dijck in het tijdschrift Feit \& Fictie de aandacht op de cultuurkritische functie van New Journalism. De stroming trachtte met behulp van nieuwe journalistieke vormen betekenis te geven aan een steeds complexer wordende maatschappij, zo betoogt zij. De bekende journalistieke middelen konden de veranderde werkelijkheid niet langer adequaat weergeven. 'Nieuwe journalisten' toonden in hun stukken ambivalentie en verschillende standpunten, en lieten de genres journalistiek en literatuur botsen om hun twijfel aan de bestaande communicatie- en tekstvormen uit te drukken. De persoonlijke wijze van berichtgeving analyseert Van Dijck, in navolging van David L. Eason, als kritiek op de journalistieke conventies, die de interpreterende rol van de journalist aan het oog onttrekken. Nieuwe journalistiek was met andere woorden een 'meta-taal'; een reflectie op het schrijven zelf als vorm van betekenisgeving. ${ }^{3}$

Deze (cultuur)kritische component maakte New Journalism in de context van de jaren zestig en zeventig politiek van aard. De progressieve politiek van deze periode beperkte zich niet tot het traditionele politieke domein, maar manifesteerde zich in de hele samenleving. Het dagelijks leven was doortrokken van politiek, zo meenden progressieve politici en activisten, en burgers moesten daarvan bewust worden gemaakt. Dan konden ook 'gewone mensen' een duidelijke politieke keuze maken en uitdragen; door middel van een (progressief-politieke) levenshouding konden zij hun eigen leven en de samenleving vorm geven. De individuele en creatieve mens werd zo de motor in het politieke proces. De (progressieve) politiek van de jaren zestig en zeventig was dus persoonlijk van aard, en maakte het persoonlijke politiek. ${ }^{4}$ Deze notie kan de functie en betekenis van New Journalism verhelderen, en tevens de 'politieke' interpretatie van het verschijnsel tijdens en vlak na zijn optreden - en de 'literaire' duiding ervan in later jaren - met elkaar in verband brengen. De nieuwe, persoonlijke en kunstzinnige vormen in de journalistiek waren in zichzelf subversief omdat zij de bestaande conventies en autoriteiten ondermijnden. Maar zij waren ook politiek in hun pogingen de lezers aan te sporen zelf na te denken, zich te verdiepen in hun eigen situatie en die van anderen, en hun verantwoordelijkheid te nemen. Door de wereld op een andere, minder vanzelfsprekende wijze te tonen, schiepen de nieuwe journalisten de ruimte en daarmee de mogelijkheid om deze te veranderen.

Aan de hand van een analyse van contemporaine stukken van en over nieuwe journalisten zal deze redenering worden uitgewerkt en aannemelijk gemaakt. Op basis van deze interpretatie van het fenomeen New Journalism zullen vervolgens vormen van 'nieuwe journalistiek' in Nederland worden gedetermineerd. Hoewel New Journalism in Europa niet bijzonder veel werd 'toegepast', , is in Nederland in de jaren zeventig werk van Hunter Thompson vertaald, en werd Tom Wolfe meerdere malen geïnterviewd. Met name de tijdschriften Haagse 
Post en, in mindere mate, Intermagazine (in I98I ontstaan als zelfstandig weekblad uit het magazine van Intermediair, en in I992 samengevoegd met de glossy Avenue) leverden een bijdrage aan de ontwikkeling van een Nederlandse 'nieuwe journalistiek'. In deze bladen ging het vooral om reportages. De interviews van Bibeb (E.M. Lampe-Soutberg) in Vrij Nederland en van Ischa Meijer kunnen echter, als 'reportages over personen', ook tot de exponenten van New Journalism worden gerekend. Verder zal aandacht worden besteed aan de documentaire Vastberaden maar soepel en met mate uit 1976. Een van de makers, H.J.A. Hofland, bracht deze 'reportage op de televisie' expliciet in verband met de 'nieuwe journalistiek'. Een 'politieke' opvatting van New Journalism maakt het mogelijk deze journalistieke experimenten niet, zoals vaak gebeurt, te zien als een kleinschalig en weinig invloedrijk zijpad in de Nederlandse journalistiek, ${ }^{6}$ maar als inherent onderdeel van de geëngageerde journalistiek van de jaren zeventig. ${ }^{7}$

\section{Literaire nonfictie en de betere waarheid}

De journalist en (latere) schrijver Tom Wolfe legde de basis voor de interpretatie van New Journalism als een confrontatie tussen journalistiek en literatuur. ${ }^{8}$ Hij was tegelijkertijd beoefenaar en pleitbezorger van de stroming, en beschreef haar als een combinatie van technische en stilistische vernieuwingen. Nieuwe journalisten gebruiken literaire technieken, zo stelde Wolfe: zij bouwen hun stukken op in scènes en dialogen, hanteren een (persoonlijk) vertelperspectief, maken gebruik van de 'monologue intérieure' en van symbolische details. ${ }^{9}$ De nieuwe journalist schrijft niet op basis van feiten en citaten, maar probeert een ervaring zoals die zich kan hebben afgespeeld te reconstrueren. Tegenover de traditionele journalistieke vorm van de omgekeerde piramide, met de bekende 'wie, wat, waar, wanneer, waarom en hoe-vragen' en de enerzijds-anderzijds, ofwel hoor en wederhoorstijl, plaatst hij een persoonlijk en betrokken 'verhaal'.

In het verlengde hiervan vatten wetenschappers New Journalism in de eerste plaats op als literaire nonfictie. ${ }^{\text {II }}$ Ook de kritiek legde nadruk op het 'feit-enfictie-probleem'. Hoe konden nieuwe journalisten scènes en dialogen, gedachten en gevoelens weergeven zonder hun eigen verbeelding te verkopen als 'werkelijkheid'? Journalist Gay Talese stelde dat hij wel degelijk dergelijke zaken kon beschrijven zonder te fictionaliseren. Hij volgde zijn personages in allerlei situaties en noteerde nauwgezet hun reacties en die van anderen op hen. Hij nam scènes, dialogen en sfeer in zich op, om ze vervolgens op te schrijven vanuit het gezichtspunt van een van de personages. Hij kon te weten komen wat mensen voelden door hen daarnaar te vragen in interviews. ${ }^{\mathrm{I} 2}$ Critici suggereerden dat nieuwe journalisten vooral uit waren op verhoging van hun eigen status; die van een literator was groter dan die van een persmuskiet. Wolfe bevestigde dit beeld 
door te stellen dat elke journalist, nieuw of oud, in diepste wezen een roman wilde schrijven, of zelfs 'The Great American Novel'.

Het ontstaan van deze literaire journalistiek wordt doorgaans gezien als een reactie op de gebeurtenissen en de maatschappelijke en culturele veranderingen in de jaren zestig; nieuwe thema's vroegen toen om een nieuwe vorm. Het jaar I968 was een brandpunt in de politieke berichtgeving: de anti-Vietnamprotesten bereikten een hoogtepunt, rellen omlijstten de democratische conventie in Chicago, Martin Luther King en Robert Kennedy werden vermoord. In dat jaar gingen veel toonaangevende tijdschriften ertoe over romanschrijvers aan te trekken om literaire reportages te schrijven als 'impressionistic versions of contemporary history'. ${ }^{14}$ De eigen tijd had grote historische betekenis, was het idee; het waren unieke jaren, die veranderingen lieten zien die niet voor mogelijk waren gehouden, en die wel eens een waterscheiding in het menselijk bewustzijn konden blijken te zijn. ${ }^{\text {I5 }}$

'The realm of the believable had become an extremely doubtful concept.' En 'it was only by allowing imagination into journalism that journalism could speak to the imagination of the times'.

Daarmee verloren de verschillen tussen journalistiek en literatuur aan betekenis; was de literatuur zelfs noodzakelijk om betekenis te geven aan de gebeurtenissen. De jaren zestig konden niet 'neutraal' worden benaderd, aangezien de essentie van dit tijdperk lag in sfeer en emotie, en in veranderingen in conventie en moraal. Andere manieren van denken en gedrag, en verschillende leefstijlen en subculturen vroegen om nieuwe wijzen van representatie. ${ }^{16}$

De aandacht voor verbeelding en de keuze van andere vormen kwamen niet alleen voort uit de behoefte bijzondere gebeurtenissen en ontwikkelingen mooier op te schrijven; nieuwe journalisten wilden ze ook béter weergeven. New Journalism stelde het vermogen tot objectieve berichtgeving waarvan de traditionele journalistiek uitging, ter discussie. Objectiviteit was onmogelijk, en alleen al daarom was het onwenselijk ernaar te streven. De selectie van feiten zorgde ervoor dat nooit het 'hele verhaal' werd verteld. Nieuws werd 'gemaakt' door de overheid, door voorlichters, en door journalisten. ${ }^{\text {r7 }}$ Het doen alsof een reporter neutraal, afstandelijk en objectief kon zijn, hinderde volgens nieuwe journalisten juist de zoektocht naar de (persoonlijke, creatieve, maatschappelijk relevante) 'waarheid'. De conventionele journalistiek was hierdoor oneerlijk tegenover de lezer en tegenover zichzelf. Nieuwe journalisten stelden zichzelf daarom op als aanwezige personen, desnoods in de ik-vorm, als een laag van bewustzijn tussen de gebeurtenissen en de lezer, in plaats van als een neutraal medium. Literaire technieken of een opvallende stijl (bijvoorbeeld de typografische eigenaardigheden van Wolfe) vestigden eveneens de aandacht op de rol van de auteur. ${ }^{\mathrm{I}}$

New Journalism reflecteerde op het eigen vakgebied, bijvoorbeeld in het journalistenvakblad The Quill, in de Columbia Journalism Review en in The Atlan- 
tic Monthly. Er werden anthologieën samengesteld, bijvoorbeeld het boek The New Journalism dat in I973 verscheen met een inleiding van Wolfe; en bundels met stukken óver New Journalism van uitgevers, critici en nieuwe journalisten zelf. ${ }^{19}$ De schrijver Norman Mailer onderzocht in The armies of the Night op welke wijze journalistiek, literatuur en geschiedschrijving de werkelijkheid weergaven. Het boek bestond uit twee delen: 'The novel as history' en 'History as the novel'. Mailer speelde een leidende rol in de anti-Vietnamdemonstratie bij het Pentagon - die hij beschrijft - en wilde voorkomen dat een verkeerde weergave daarvan door de massamedia toekomstige historici zou beïnvloeden. De ambiguïteit van de gebeurtenissen maakte het echter moeilijk voor hem ze te plaatsen in een grotere (historische) context. Steeds als hij er betekenis aan probeerde te geven, zag hij zichzelf een roman schrijven;

'all experience except that limited to meaningless surface inquiry, all knowledge which goes beyond mere gathering of data, is inherently fictional'. ${ }^{\circ}$

De nieuwe journalisten stelden dus de claim op objectiviteit van hun eigen vakgebied ter discussie, en trachtten helderheid te verschaffen door subjectief te zijn. Zij wilden gebeurtenissen en verschijnselen wegen en beoordelen, betekenis geven en verklaren. Zij streefden naar een andere vorm van 'waarheid', die authentiek, persoonlijk en gelaagd was, en hun meningen, ideeën en betrok-

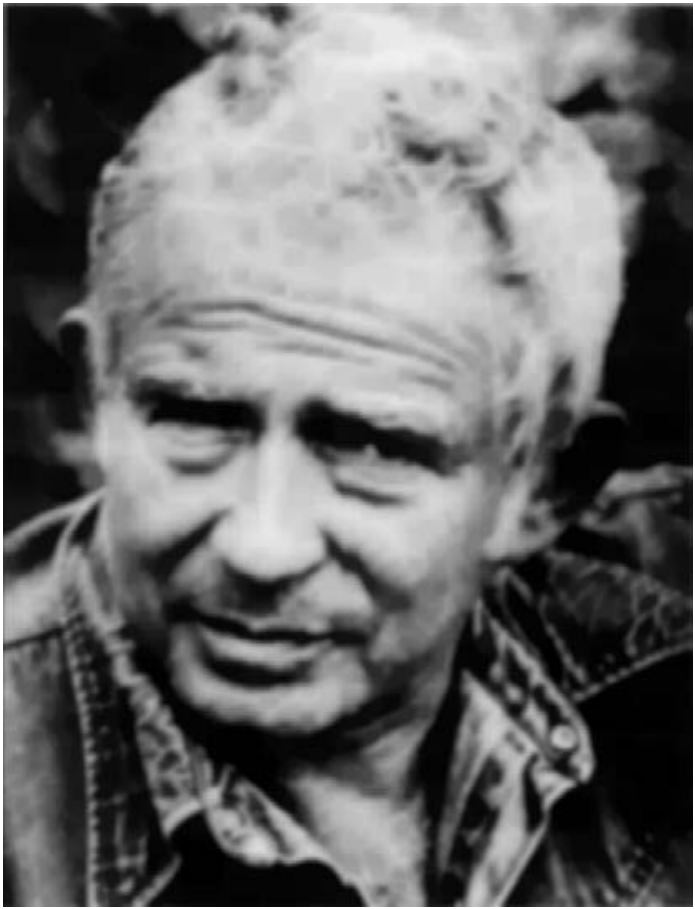

Norman Mailer (*1923) in de jaren zeventig. Bron: G. Vermeulen, Het tijdschrift, Amsterdam 1980 kenheid expliciteerde. ${ }^{21}$ Nieuwe journalisten verlieten zich niet op de traditionele nieuwsbronnen. Zij belden geen experts, maar gingen op onderzoek uit en vormden zelf hun oordeel. Afstandelijke berichtgeving op basis van citaten en feiten was volgens hen niet betrouwbaar; een ingebouwd waardesysteem bij de autoriteiten en bij de traditionele journalistiek zelf maakte haar blind tegenover een belangrijk deel van de werkelijkheid. De lezer kon en moest daarop worden gewezen door hem nieuwe nieuwsbronnen ter beschikking te stellen, waarin verschillende visies tegen elkaar werden afgezet. Een nieuwe journalist behoorde namens geen enkele instantie te spreken, maar alleen zijn eigen geweten in te schakelen bij beoordeling en meningsvorming. ${ }^{22}$ 
New Journalism ging op zoek naar een 'andere' waarheid, naar 'a larger truth'. En naar een verhaal dat 'unvarnished and plain and human' was, en daardoor 'true, truer than any facts'. In een paneldiscussie, gehouden in januari I970, zei Gay Talese dat voor Wolfe en voor hemzelf verifieerbare feiten niet genoeg waren. 'Not enough to get a fraction of the truth.' Wolfe zelf stelde dat nieuwe journalisten iets toevoegden aan de traditionele waarheid; 'something that readers had always had to go to novels and short stories for: namely, the subjective or emotional life of the characters'. ${ }^{23}$ Deze zoektocht naar een betere waarheid was persoonlijk van aard. 'Literary journalism' is niet voor niets vaak aangeduid met de wat in vergetelheid geraakte term 'personal journalism'. De persoon van de auteur drukte zijn stempel op het feitenmateriaal om de geloofwaardigheid te versterken. De nieuwe journalist stond in zijn eigen werk centraal als creatief en verantwoordelijk individu. Door zijn openlijke subjectiviteit ademde zijn werk zijn oordelen, emoties en persoonlijkheid. ${ }^{24}$ De kritiek op New Journalism richtte zich ook op dit aspect: auteurs als Mailer en Wolfe zouden de hele wereld in de persoon van de schrijver centreren, en kennis opofferen aan 'a parading of personality'. ${ }^{25}$ Publicist en nonfictie-auteur Dan Wakefield zag echter in I966 de aanwezigheid van de persoon van de journalist als een belangrijke, interessante en hoopvolle trend. ${ }^{26}$ Een trend die de relatie tussen de journalist en de lezer zou veranderen.

\section{Het politiek gehalte van New Journalism}

Aan het begin van de jaren zeventig werd New Journalism breder opgevat dan in later jaren. Het ging niet alleen om 'literaire' journalistiek. Communicatiewetenschapper Michael L. Johnson noemde in zijn boek uit I97I uiteenlopende verschijningsvormen: de 'underground press' als geheel, actuele essays van journalisten en literatoren, vernieuwing van het genre reportage. Zijn collegae Everette E. Dennis en William L. Rivers hanteerden in I974 een brede definitie met maar liefs zeven sub-genres: 'new nonfiction', 'alternative journalism', 'journalism reviews', 'advocacy journalism', 'counterculture journalism', 'alternative broadcasting' en 'precision journalism'. ${ }^{27}$ Het politieke aspect stond in al deze vormen van journalistiek op de voorgrond, maar 'politiek' had in deze periode een andere, en bredere betekenis dan tegenwoordig. Politiek speelde ook 'in de huiskamer' waar de individuele burger zich bewust moest worden van machtsstructuren en onderdrukkingsmechanismen enerzijds, en van zijn eigen creativiteit en mogelijkheden om de maatschappij te veranderen anderzijds. Dit politieke element is vanaf het begin van de jaren tachtig niet meer als zodanig herkend. Impliciet is het wel aanwezig in Van Dijcks 'cultuurkritische' analyse.

New Journalism was begin jaren zeventig vooral participerende journalistiek, die zich bezighield met nieuwe sociale bewegingen en maatschappelijke 
problemen. Deze journalistiek kwam, evenals de 'literaire' journalistiek en de reflectie op het eigen vakgebied, voort uit het streven naar een betere waarheid. Nieuwe 'underground' journalisten zochten de 'andere' kanten van het nieuws bij linkse politieke partijen, actiegroepen en jongerenorganisaties, die in de media steevast verkeerd zouden worden ge(re)presenteerd. Vernieuwingsgezinde journalisten trokken intens en bij voorkeur langdurig op met leden van bevrijdingsbewegingen, met 'new left'-politici en -activisten, met feministen en milieuactivisten, met musici, hippies en drugsgebruikers. Door het kiezen van obscure onderwerpen stelden zij de officiële politieke agenda ter discussie. Amateurs die zonder financiering alternatieve krantjes volschreven, vormden volgens sommigen de werkelijke 'nieuwe journalistiek'. ${ }^{28}$

De intensieve bemoeienis met alternatieve bewegingen werkte betrokkenheid in de hand. De gehanteerde onderzoeksmethode van de 'participerende observatie' maakte reporters tijdelijk tot onderdeel van een groep. En hoe dichter een journalist bij zijn onderwerp komt, des te begripvoller hij wordt tegenover ideeën, houdingen en gevoelens van de personen die hij volgt. ${ }^{29}$ De onderwerpen die deze journalisten aansneden, zoals racisme en de Vietnam-oorlog, waren bovendien niet neutraal, zo stelden zij, en konden daarom ook niet op neutrale wijze worden beschreven. De New Journalists werden gedreven door sociale bewogenheid en door ontevredenheid met de bestaande situatie. Door hun kritische opstelling en streven naar verandering van de maatschappij werd schrijven een politieke activiteit. Veel journalisten committeerden zich aan bepaalde politieke bewegingen. Niet voor niets werd de term 'newsroom revolution' gebezigd. ${ }^{30}$

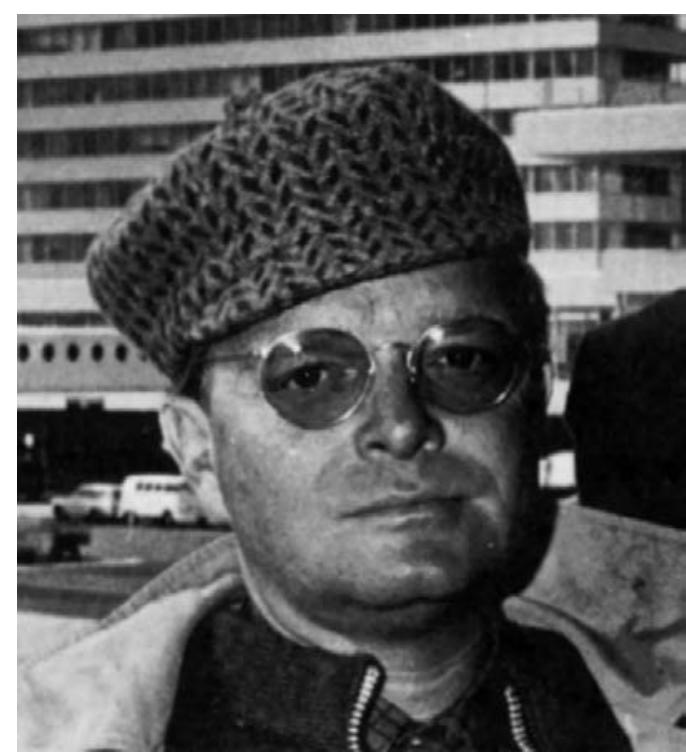

Truman Capote (1924-1984) in de jaren zeventig. Bron: G. Vermeulen, Het tijdschrift, Amsterdam 1980
Maar het politieke karakter van New Journalism werd in essentie niet bepaald door betrokkenheid bij deze of gene (politieke) zaak. Het was de persoonlijke en betrokken wijze van verslaggeven die zo'n duidelijke politieke connotatie had. Dit verbond de 'underground press' met de literaire journalistiek bij de meer gevestigde bladen. Truman Capote, auteur van de 'nonfiction novel' In cold blood, zei in I966 in een interview dat hij de lezer zelf meerdere gezichtspunten en interpretaties wilde laten beoordelen: 'Instead of presenting the reader with a full plant, with all the foliage, a seed is planted in the soil of his mind. ${ }^{31}$ Wolfe wilde de lezer zowel intellectueel als emotioneel 'involveren'; alleen door een 'dramatische' of 'lite- 
raire' benadering konden journalisten hun directe betrokkenheid en actieve participatie overbrengen, meende hij. Direct, persoonlijk en verbeeldingsvol schrijven betekende namelijk: terugkeren naar 'the language of the common man', naar zijn dagelijks leven en emoties. ${ }^{32}$

De betrokkenheid van de nieuwe journalisten genereerde betrokkenheid bij de lezer; nonfictie-schrijver Nat Hentoff zei over Mailer: 'his involvement draws you in as no traditional news account possibly could'. Op deze wijze kon New Journalism 'help break the glass between the reader and the world he lives in'. Volgens Hentoff moest een burger meer dan slechts 'geïnformeerd' zijn; alleen de feiten waren niet genoeg om te beseffen wie hij was en wat zijn rol in de samenleving was. Betrokkenheid was nodig om hem te laten handelen, en zijn en andermans lot in eigen handen te nemen. ${ }^{33}$ Een kritische houding ten opzichte van autoriteiten, het betrokken zijn bij en het streven naar maatschappelijke veranderingen, het bewust maken en mobiliseren van de 'gewone man'; dit is in een notendop de kern van de progressieve politiek van de jaren zestig en zeventig. Het is ook de kern van de 'nieuwe journalistiek'.

\section{Persoonlijke journalistiek en engagement}

In journalistieke handboeken en historische literatuur wordt New Journalism in Nederland een beperkte invloed en reikwijdte toegedicht. De stroming zou zich bijna uitsluitend hebben gemanifesteerd bij het tijdschrift de Haagse Post, in de jaren zeventig en tachtig. De kern van de 'New-Journalism'-experimenten bij de Haagse Post wordt vaak gezocht in de samenwerking met literatoren, die in de jaren tachtig een hoogtepunt bereikte. Het blad oriënteerde zich toen expliciet op Amerikaanse tijdschriften als Esquire. ${ }^{34}$ Dit was echter New Journalism volgens de enge jaren-tachtiginterpretatie: literatuur in tijdschriftvorm. De lange schrijversportretten en korte verhalen, en enorme artikelen over historische onderwerpen, hadden geen zichtbare maatschappelijke relevantie. De literaire nonfictie werd deels verdrongen door 'echte' fictie. Voormalige Haagse Postredacteur Joost Niemöller kenschetste de toon als van een grote 'onthechtheid': 'Mooi opschrijven. Veel sfeer. Geen boodschap. ${ }^{35}$

Als New Journalism wordt opgevat als een politieke stroming, waarin de literaire vorm en persoonlijke benadering bedoeld waren om betrokkenheid te genereren, bewust te maken en de individuele mens als politieke factor te mobiliseren, moeten de wortels van een Nederlandse 'nieuwe journalistiek' al in de jaren zestig worden gezocht, en niet alleen bij de Haagse Post. Dit tijdschrift was in de jaren zeventig echter wel de duidelijkste en meest expliciete exponent ervan. Het volgde de ontwikkeling van New Journalism in Amerika op de voet. ${ }^{36}$ H.J.A. Hofland verwees naar het werk van Hunter Thompson, met name naar de vertaling van diens boek over Nixons verkiezingscampagne van I972. Haagse 
Post-redacteur Daan Dijksman interviewde in november I976 Tom Wolfe; in maart I976 was al een interview verschenen met Truman Capote. ${ }^{37}$ De redactie volgde ook in bredere zin de gebeurtenissen in de Verenigde Staten; zo versloeg Jan Donkers uitgebreid de Watergate-affaire. Martin Schouten gaf later aan te zijn beïnvloed door Studs Terkel, wiens 'oral history' van de Great Depression met New Journalism wordt geassocieerd. ${ }^{38}$

H.J.A. Hofland expliciteerde in I975 de band van 'De Nieuwe Journalistiek' met het Amerikaanse New Journalism. Hij stelde dat 'de waardige, traditionele en afstandelijke manier om de feiten over te brengen' niet langer toereikend was. De huidige berichtgeving stond te ver bij de lezer vandaan en verschafte hem geen opheldering 'over (...) zijn eigen lot'. Onwelkom nieuws werd ontdaan van de emotionele en persoonlijke aspecten en in afgezwakte taal, in eufemismen beschreven. Wat overbleef was een 'gemiddelde gebeurtenis' die 'geen enkele betrokkenheid' meer opriep. Mede door het informatiemonopolie van de overheid werd zo door de journalistiek de status quo bevestigd. In deze uitleg van Hofland zijn precies de elementen terug te vinden die New Journalism zijn politieke betekenis gaven, hoewel Hofland benadrukte dat nieuwe journalisten geen bedoeling tot beïnvloeding in een bepaalde (politieke) richting hadden. Persoonlijke en emotionele berichtgeving genereerde - in tegenstelling tot de traditionele afstandelijke journalistiek - betrokkenheid, of in de termen van de jaren zeventig: 'engagement'. De burger werd bewust gemaakt, of in de woorden van Hofland: de burger ging begrijpen dat hij

'deelnemer is aan een onverwachte actualiteit. Alleen op grondslag van die betrokkenheid kan een inzicht worden verworven en alleen daarna ontstaat het behoorlijke oordeel dat een mens van zijn schlemielenschap ontlast. ${ }^{39}$

De journalistieke benadering die Hofland beschreef, ging bij de Haagse Post terug tot het einde van de jaren zestig. Toen werd een groepje auteurs actief dat naar hun voorman wel de 'school-Armando' heette, en zichzelf (gekscherend, maar toch) omschreef als de school van het 'gouden pennetje'. Deze redacteuren besteedden veel aandacht aan stijl en compositie, en kozen op het eerste gezicht weinig nieuwswaardige onderwerpen. Iemand als Cherry Duyns blonk uit in het opsporen van obscure thema's, liet zijn 'personages' denken en voelen, en beschreef scènes waarbij hij onmogelijk aanwezig kon zijn geweest. Zo schreef hij een ironisch stuk over de 'eugeneticus' H.J. van Unen, waarin hij op impliciete en op het oog niet sturende, maar toch op niet mis te verstane wijze, de vraag opwierp of deze man een racist was of niet. Hij deinsde ook niet terug voor een expliciet geëngageerde opstelling, zoals blijkt uit zijn karakterisering van ombudsman Marcel van Dam als een 'actuele Robin Hood': 'Politici kunnen wat van hem leren. ${ }^{4 \circ}$ Duyns en de zijnen worden niet gerekend tot de 'nieuwe journalistiek', omdat zij zelf als verteller 'afwezig' bleven. Het schrijven vanuit personages - en dat deden zij juist wel - was echter ook een literaire techniek die New Journalists gebruikten om van een gebeurtenis een 'reconstructie' te 
maken, in plaats van een compositie van feiten en citaten 'achteraf. De 'terughoudendheid' en 'permanente ironie' die de Haagse Post-redacteuren tentoonspreidden, de marginale onderwerpen en nauwkeurige observaties, getuigden bovendien niet van afstandelijkheid, maar van pogingen om de 'grotere waarheid' te vinden die verborgen lag achter de officiële informatie, de vaststaande ideologieën en de 'partijdige' journalistiek. Die betere waarheid heette bij hen 'emotie', en was wel degelijk bedoeld om 'alles neer te halen'. ${ }^{11}$

Begin jaren zeventig kreeg de Haagse Post onder leiding van adjunct-hoofdredacteur Hans Sleutelaar een duidelijker politiek profiel. Een nieuwe generatie van academisch geschoolde redacteuren trad aan, onder wie A.J. Heerma van Voss, die in I974 volledig werd vrijgemaakt om de Dennendal-affaire van binnenuit de kunnen volgen. De 'politisering' van de Haagse Post paste in een politisering van kunst en journalistiek, maar ook van het voorheen in Nederland vooral 'ludieke' actiewezen, die toen zichtbaar werd. Zo werd het jongerenblad Hitweek opgevolgd door Aloha, dat veel minder aandacht besteedde aan popmuziek, en serieuzer, geëngageerder en politieker was dan zijn voorganger. Roel van Duyns 'Kabouter'-beweging, opvolger van Provo, kreeg dankzij achtendertigduizend stemmen vijf zetels in de Amsterdamse gemeenteraad. In de studenten- en de vrouwenbeweging kregen concrete politieke doelen en dwingender manieren van actievoeren de overhand. ${ }^{42}$

De Haggse Post schreef nu behalve over traditionele linkse onderwerpen als de vakbeweging, ook over milieuvervuiling - een thema dat was opgepikt door de nieuwe hoofdredacteur W.L. Brugsma -, over studentenactivisme, psychiatrie, derdewereldproblematiek, bevrijdingsbewegingen en dictatoriale regimes (in Angola, Chili, Zuid-Afrika, Spanje, Portugal en Griekenland). ${ }^{43}$ De 'stilisten' met hun belangstelling voor de leefwereld van de gewone man konden met deze thema's net zo goed uit de voeten als de 'doctorandussen'; en het werk van beide groepen was in de opvattingen van de jaren zeventig politiek. Het gezamenlijke uitgangspunt was, dat journalistiek moest gaan over concrete zaken en individuele mensen. Betty van Garrel liet in haar lange reportages 'gewone mensen' aan het woord, niet uit vrijblijvende interesse voor hun leefwereld, maar om de aandacht te vestigen op kleine misstanden met grote maatschappelijke betekenis, zoals (industriële) geluidsoverlast. Wiliam Rothuizen beschreef de Amsterdamse Bijlmer als 'proeftuin' van tolerantie en nieuwe leefvormen, op basis van 'gesprekken met alleenstaanden, homofielen, Surinamers en Antillianen'. Daardoor emancipeerde hij deze groepen, en maakte hij een politieke statement; hij schilderde de wijk af als een utopia, voorbij de vraag van 'mooi of niet mooi?'. Rothuizen ging ook op bezoek bij crèches, en wierp in zijn precieze beschrijving van het dagelijks gekeutel de vraag op, of anti-autoritaire, 'doehet-zelfcrèches' een aanbevelenswaardige ontwikkeling waren of niet. ${ }^{44}$

Het duo Kees Tamboer en Frans Nypels schreef politieke reportages 'van binnenuit' (progressieve) politieke partijen en groepen, in scènes en dialogen, met opneming van sprekende details. Zij drongen zelfs door tot de minister- 
raad. In 'Oorlog en vrede in het Catshuis' schreef Tamboer over Henk Vredelings uitvallen en 'onberekenbaarheid', over Ruud Lubbers die 'afkoeling' zocht in de tuin van het Catshuis, en over Joop den Uyl die zich terugtrok in de slaapkamer op de eerste verdieping, waar Wim Duisenberg hem moed kwam inspreken. ${ }^{45}$ Niet alleen Cherry Duyns, die nu ook optrad als politiek verslaggever, maar ook de veel zakelijker Tamboer typeerde politici in sprekende portretten die waren gebaseerd op nauwgezette observatie van voorkomen en motoriek. Tamboer beschreef bijvoorbeeld Wiegel als volgt:

'De studentikoze gelaatsuitdrukking is vervangen door verbeten trekken.

Terwijl hij vroeger bestudeerd-zelfverzekerd door de gangpaden van 's lands vergaderzaal liep te kuieren, heeft hij zich nu een krampachtige, wat waggelende loop aangemeten alsof zijn paard onder hem weggelopen is. ${ }^{{ }^{46}}$

Vanaf ongeveer I976 tot I982 worden de jaargangen van de Haagse Post steeds dikker, vanwege de toenemende lengte van de reportages. De verslaggevers traden 'uit de coulissen', en maakten hun 'luimen en emoties' tot onderdeel van hun reportages. Martin Schoutens artikelen over jazzmuziek worden vaak genoemd als voorbeelden van literaire journalistiek, maar hij schreef ook over politieke en maatschappelijke kwesties. Zo woonde hij in I976 een bijeenkomst bij van Proloog en andere linkse toneelgroepen. In I979 berichtte hij uitgebreid over het armoedige leven in de mijnstreek na de sluitingen. ${ }^{47}$ Jantiene van Aschs trok wekenlang op met sekteleden, neonazi's, of bewoners van een psychiatrische instelling of vrouwenhuis. Zij noteerde gedetailleerd wat zij zag, en maakte zichzelf tot onderdeel van de betreffende subcultuur. ${ }^{48}$ Martijn de Rijk reisde begin I976 af naar Christiana, een hippiewijk in Kopenhagen, om het leven aldaar te beschrijven. De bewoners noemde hij bij hun voornamen als goede vrienden, en hij beschreef uitgebreid zijn in eerste instantie weinig succesvolle pogingen om door te dringen tot dit wereldje. Verder vertoefde hij in een gezinstehuis, en in 'de wereld van de junkies' op de Amsterdamse Zeedijk. ${ }^{49}$ Leon de Wolff zette de traditie van 'inside'-reportages over de PvdA voort. Zo zag hij dat op een besloten bijeenkomst ten kantore van André van der Louw 'flauwe grappen' werden verkocht 'over het lichtgevende kunstobject dat in een van de hoeken van André's werkkamer een plaats heeft gekregen'. Impliciet schreef hij zo over de verhouding tussen vriendschap en politiek. In I982 stelde hij een tientallen pagina's lang 'dossier-Den Uyl' samen, waarin hij als in een roman de gevoelens en gedachten beschreef van zijn hoofdpersoon, tijdens een contemplatief moment naast de auto langs de snelweg of in een lege congreszaal..$^{50}$

Toen de benadering van de Haagse Post begin jaren tachtig steeds 'literairder' werd, trachtte het nieuw opgerichte tijdschrift Intermagazine, waarvan Haagse Post-redacteur Bert Vuijsje halverwege het jaar i981 hoofdredacteur werd, een meer maatschappelijk-relevante nieuwe journalistiek voort te zetten. Vuijsje hervormde het blad vanuit een streven naar 'een grotere levendigheid en variatie en vooral naar het opbouwen van een eigen journalistieke identiteit'. Aan het 
blad ging een groot aantal (voormalige) Haagse Post-redacteuren meewerken, zoals Betty van Garrel, Ischa Meijer, Paul van Engen, Lieve Joris en Leon de Wolff. Korte verhalen en reisreportages wisselden lange interviews, uitgebreide portretten en participerende reportages af. De auteur had in alle stukken een belangrijke rol als personage of commentator. ${ }^{5 \mathrm{I}}$

De interviews van Ischa Meijer waren, net als die van zijn voorbeeld Bibeb, eigenlijk zeer persoonlijke reportages, die gingen over één persoon. Door deze invulling van het genre kunnen de stukken van Meijer en Bibeb worden gerekend tot de 'nieuwe journalistiek'. Zij verkregen hun informatie door zelfstandig onderzoek (namelijk lange gesprekken met de geïnterviewden) en nauwkeurige observatie. Alleen al vanwege de lengte van hun stukken spoorden zij de lezer aan zelf zijn weg te vinden en een eigen oordeel te vormen. New Journalism was in essentie persoonlijk, in het optreden van de verslaggever, maar ook 'in that it tells about people, who they are and what makes them tick'. ${ }^{52}$ Bibeb en Meijer trachtten een beeld te schetsen van (vooraanstaande) personen; zij plaatsten hun uitspraken in de context van hun karakters. Bibeb interviewde al in de jaren vijftig en zestig voor Vrij Nederland beroemdheden volgens deze werkwijze. ${ }^{53}$ Ze trok dagenlang op met haar 'slachtoffers' en trachtte diep tot hen door te dringen. Eind jaren zestig en vooral in de jaren zeventig legde zij steeds vaker bekende politici op haar divan. Haar vermogen de politici onverwachte uitspraken te ontlokken en te tonen 'wie zij werkelijk waren' - achter de façade van officiële informatie en geregisseerde uitspraken - toonde politici als 'gewone mensen'. Niet de politieke opvattingen stonden centraal, maar de emoties en het persoonlijk leven. Lange beschrijvingen van hun uiterlijk, houding en gedrag wisselden uitgebreide full quotes en korte interpreterende opmerkingen van Bibeb zelf af; dit alles in een verbeeldingsvolle, om niet te zeggen literaire stijl.

Bibebs bekendste interview vond plaats in I974. Minister van Defensie Vredeling vertelde, voor de duidelijkheid vermeldend 'ik zuip altijd zoals je weet', uitgebreid over zijn oorlogservaringen, over zijn 'baantje' en over zijn collegae 'Corpspik' Jan Pronk, Ruud 'weet-ie veel'-Lubbers en Max van der Stoel die achter zijn ambtenaren aanliep 'met z'n bekkie'. Aan het einde van het interview zei Vredeling dat hij het gevoel had te moeten aftreden, maar: 'als ik daarmee door het behang ga, dan wil ik niet eens meer minister wezen' ${ }^{54}$ Bibebs stukken maakten duidelijk dat persoonlijkheid een politieke factor was en dat het persoonlijke politiek was.

Ischa Meijer schreef in het begin van de jaren zeventig enkele reportages over Israël in de Haagse Post, maar werd veel bekender met zijn interviews voor de Haagse Post en Intermagazine, en later voor Vrij Nederland. ${ }^{55}$ Hij plaatste aanvankelijk zijn werkwijze, en zichzelf als auteur, nadrukkelijk tussen de geïnterviewde en de lezer. Zo schreef hij aan het begin van een interview met W.F. Hermans:

'Het hieronder afgedrukte gesprek met Willem Frederik Hermans is niet door de geïnterviewde gelezen, gecorrigeerd of geautoriseerd. De uitdrukke- 
lijke afspraak luidt: alles wat naar aanleiding van het gesprek (donderdagmiddag 22 oktober ten huize van de schrijver te Haren (Gr.)) genoteerd en gepubliceerd wordt komt voor de rekening van de interviewer (...). Het interview duurde tweeëneenhalf uur en werd door middel van een tape-recorder geregistreerd..$^{56}$

Meijer benadrukte, als hij over zijn werkwijze vertelde, zijn eigen sturende rol in het interview. Hij construeerde zijn stukken later als strate quotes:

'De taak die ik mijzelf gesteld heb, is, dat elke monoloog speelbaar moet zijn. Al mijn interviews bevatten schijnbaar onzichtbare regie-aanwijzingen. Iedere overgang is op theatraal effect aangebracht. De protagonist - die nooit bij name wordt genoemd, maar als prototype - wendt zich nooit ofte nimmer tot mij, maar spreekt richting zaal, tegen een anoniem publiek. De minst geringe verwijzing naar de situatie waarin het eigenlijke gesprek plaatsvond, is weggewist.'

Meijer creëerde in zijn interviews dus een nieuwe werkelijkheid die ver af stond van het gesprek zoals dat had plaatsgevonden. Het doel van deze constructie en de fictionele vorm was de wereld begrijpelijk te maken voor hemzelf, waardoor hij, hoewel niet zichtbaar, zichzelf als auteur nog steeds op de voorgrond plaatste. ${ }^{57}$

Volgens Nederlandse journalisten werd een Nederlandse 'nieuwe journalistiek' behalve bij de Haagse Post beoefend in televisieprogramma's als B ERICH TEN UIT DE SAMENLEVING en HET GAT VAN NEDERLAND, en in documentaires. De televisiefilm VASTbERADEN MAAR SOEPEL EN MEt MATE. HeRINNERINGEN AAN NEDERLAND I938-I948 uit I974 werd door een van de makers, Hofland, als zodanig aangekondigd. Voor zijn inleiding op de tekstuitgave gebruikte hij zijn Haagse Post-artikel over de 'nieuwe journalistiek' uit maart I975. ${ }^{58}$ In deze televisiereportage zijn de literaire en politieke aspecten van New Journalism inderdaad terug te vinden. Chris Vos beschrijft in het Jaarboek Mediageschiedenis van I993 hoe de kijker zelf zijn weg moet vinden in de lange film, die geen sturend commentaar bevat, maar een caleidoscoop is van interviews en tijdsdocumenten. Betekenisvolle fragmenten worden aan elkaar geplakt tot een nieuwe waarheid. VASTB ERADEN wil afrekenen met een overheersend beeld van, in dit geval, de bezettingsperiode, en levert kritiek op daarmee samenhangende machtsvraagstukken als de continuiteit in de elites voor en na de oorlog. Emoties en persoonlijke details worden benadrukt, om de aandacht te richten op de beleving van gewone mensen. Daarnaast is de film persoonlijk door de opstelling van de makers: zij verdoezelen hun standpunten niet, en geven persoonlijk commentaar, op 'soms zelfs poëtische toon'. De documentaire wil, als pendant van een literaire journalistiek, aansluiten bij een filmische esthetiek, en hanteert wat dit betreft de 'vP RO-stijl' die ook bovengenoemde programma's kenmerkt. ${ }^{59}$ 


\section{Persoon en politiek}

New Journalism toont dat in de jaren zestig en zeventig politiek persoonlijk was, en het persoonlijke politiek: alleen door de bewustwording van de individuele mens kon de politieke en maatschappelijke werkelijkheid worden veranderd. De literaire vorm van New Journalism diende niet slechts een esthetisch doel, maar moest de informatie dichter bij de lezer brengen; daardoor kon de 'gewone man' worden gepolitiseerd. Tegenover de 'objectieve', officiële berichtgeving werden alternatieve reportages geplaatst, die waren geschreven op basis van eigen onderzoek, eigen oordeelsvermogen en persoonlijke beleving. Deze 'persoonlijke' journalistiek was politiek in haar kritiek op autoriteiten, in haar verbondenheid met sociale bewegingen, maar vooral in haar pogingen de relatie tussen journalistiek en lezer te veranderen met behulp van emotie en betrokkenheid. De lezer werd gewezen op de rol van de journalist in de totstandkoming van (nieuws)stukken, en werd aangespoord zichzelf een weg te zoeken in de geboden informatie en een zelfstandige mening te vormen. Tegelijk trachtte de verslaggever zijn engagement over te brengen op de lezer, en hem aan te sporen zijn lot in eigen handen te nemen. 'Nieuwe journalisten' maakten hun stukken ook begrijpelijk en invoelbaar, door hun aandacht te richten op personen, die zij opvoerden als sprekende en handelende personages.

Bekeken vanuit deze meer politieke opvatting van het New Journalism, die nader ingaat op de functie van de literaire vorm, wordt de verschijningsvorm van de stroming in Nederland zowel breder als samenhangender. 'Nieuwe journalistiek' was in Nederland niet slechts een opzichzelfstaand, kortdurend en vrijblijvend experiment bij de Haagse Post, maar manifesteerde zich ook in de interviews van Ischa Meijer en Bibeb in Intermagazine en Vrij Nederland, en in de televisiejournalistiek. Deze persoonlijke en 'literaire' journalistieke stroming verdient nader onderzoek als inherent onderdeel van de geëngageerde journalistiek van de jaren zestig en zeventig.

I. Pafionate. Tijdschrift voor de nieuwe letteren, 9, 6, nov./dec. 2002.

2. C. Harvey, 'Tom Wolfe's revenge', American Journalism Review, I6, 8, oktober I994, p. 4046, aldaar p. 4I en 46.

3. J. van Dijck, 'Cultuurkritiek en journalistiek. De discursieve strategie van new journalism', Feit Q Fictie I I, herfst I994, p. 66-78, aldaar p. 69-70 en 74; D. L. Eason, 'New Journalism, metaphor and culture', Journal of Popular Culture, I5, 4, I982, p. I42-I49, aldaar p. I43 en I45-I46.

4. Zie hierover mijn proefschrift: Heimwee naar de politiek. De herinnering aan het kabinet-Den Uyl, Amsterdam 2002; of in het kort: I. van den Broek, 'Tussen gelijk hebben en gelijk krijgen. De progressieve politiek van de jaren zestig en zeventig', Spiegel Historiael, 37, II/I2, nov.-dec. 2002, p. 493-499.

5. H. Haas \& G.-L. Wallisch, 'Literarischer Journalismus oder journalistische Literatur? Ein Beitrag zu Konzept, Vertretern und Philosophie des “New Journalism”, Publizistik. Zeitschrift für die 
Wissenschaft von Presse, Rundfunk, Film, Rheto, 36, I99I, p. 298-314, aldaar p. 310 en 298-299; K. Vidal, 'New Journalism'. Een studie over de grenzen van de journalistiek', Tijdschrift voor Sociale Wetenschappen, 38, 2, I993, p. II5-I40, aldaar p. II6 en 137.

6. R. Antonisse e.a., Journalistieke reportage. Het grote verhaal in de media, 's-Gravenhage I994, p. 35 .

7. Zie hierover: I. van den Broek, 'Engagement als deugd. Politieke journalistiek tijdens het kabinet-Den Uyl', in: J. Bardoel, F. van Vree, C. Vos en H. Wijfjes (red.), Journalistieke cultuur in Nederland, Amsterdam 2002, p. 68-82.

8. Van Dijck, 'Cultuurkritiek en journalistiek', p. 68 en 77.

9. J. Hellmann, Fables offact. The New Journalism as new fiction, Urbana/Chicago/Londen I98I, p. Ior; T. Wolfe, 'The New Journalism', in: T. Wolfe en E.W. Johnson (ed.), The New Journalism: An anthology, New York 1973, p. 3-36, aldaar p. 3I-32 en 2I; J. Hollowell, Fact \& fiction. The New Journalism and the nonfiction novel, Chapel Hill I977, p. 26-30.

Io. Hollowell, Fact \& fiction, p. 25; Hellmann, Fables of fact, p. 3 en I7.

II. R. Weber, The literature of fact. Literary nonfiction in American writing, Athens, Ohio I980, p. I-2; Hellmann, Fables of fact, p. I.

I2. G. Talese in: R. Weber (ed.), The reporter as artist. A look at the New Journalism controversy, New York i974, p. 36.

I3. Weber, The literature of fact, p. 26; Wolfe, 'The New Journalism', p. 7.

I4. Hollowell, Fact a fiction, p. 43-44.

I5. M.L. Johnson, The New Journalism. The underground press, the artists of nonfiction, and changes in de established media, Kansas I97I, p. 46; Hollowell, Fact a fiction, p. I47.

I6. Vidal 'New Journalism', p. I22-I23; Wolfe, 'The New Journalism', p. 29; Hellmann, Fables of fact, p. 8-9; M.E. Staub, 'Black Panthers, New Journalism, and the rewriting of the sixties', Representations, 57, winter I997, p. 52-72, aldaar p. 55 .

I7. Hellmann, Fables offact, p. 4; R. Weber in: Weber, The reporter as artist, p. I8; J. Newfield in: Idem, p. 6I; J.E. Murphy, The New Journalism: a critical perspective, Lexington, Kentucky I974, p. 23.

I8. Hellmann, Fables of fact, p. I5 en I04-I05; Weber, The literature of fact, p. 22-23; Weber in: Weber, The reporter as artist, p. I8; Idem, p. 73; Johnson, The New Journalism, p. 50.

19. E.E. Dennis en W.L. Rivers, Other voices. The New Journalism in America, San Francisco I974, p. 83; Wolfe en Johnson, The New Journalism; Weber, The reporter as artist; N. Mills (ed.), The New Journalism. A historical anthology, New York I974.

20. Eason, 'New Journalism', p. I47; Hellmann, Fables of fact, p. 7, 36, 38, 42 en 6r; Johnson, The New Journalism, p. 68.

2I. Haas en Wallisch, 'Literarischer Journalismus', p. 302 en 312; Hollowell, Fact \& fiction, p. II; Murphy, The new Journalism, p. 3.

22. Weber in: Weber, The reporter as artist, p. I8; J. Newfield in: Idem, p. 55 en 6r; Weber, The literature of fact, p. 25 .

23. Hellmann, Fables of fact, p. 3; Johnson, The New Journalism, p. 2I; Weber, The reporter as artist, p. 70-7I; Wolfe, 'The New Journalism', p. 2I.

24. Weber, The literature of fact, p. 22-23 en 25; Weber in: Weber, The reporter as artist, p. 20; Vidal, 'New Journalism', p. I23; Hollowell, Fact \& fiction, p. 22.

25. Weber, The reporter as artist, p. 284.

26. Haas en Wallisch, 'Literarischer Journalismus', p. 313; Hellmann, Fables of fact, p.I6; D. Wakefield in: Weber, The reporter as artist, p. 46.

27. Haas en Wallisch, 'Literarischer Journalismus', p. 303; Johnson, The New Journalism, p. xv; Dennis en Rivers, Other voices, p. v en 5 .

28. Van Dijck, 'Cultuurkritiek en journalistiek', p. 68-69; Johnson, The New Journalism, p. 6; J. Newfield in: Weber, The reporter as artist, p. 55-56 en 59; Gloria Steinem in: Idem, p. 78-79.

29. Dennis en Rivers, Other voices, p. I08; Haas en Wallisch, 'Literarischer Journalismus', p. 309; Vidal, 'New Journalism', p. I28; J. Newfield in: Weber, The reporter as artist, p. 65. 
30. Weber, The literature offact, p. 24-25; Weber in: Weber, The reporter as artist, p. 20; Haas en Wallisch, 'Literarischer Journalismus', p. 299; Dennis en Rivers, Other voices, p. I, 8, I08, I22 en I25; Johnson, The New Journalism, p. 28; Eason, 'New Journalism', p. I48.

3I. Weber, The reporter as artist, p. I96.

32. Wolfe, 'The New Journalism', p. 31; Staub, 'Black Panthers', p. 55; Johnson, The New Journalism, p. 45 .

33. Weber, The reporter as artist, p. 5I-52; Johnson, The new Journalism, p. 2I en 34; Vidal, 'New Journalism', p. I23; Weber, The literature of fact, p. 32.

34. Antonisse e.a., Journalistieke reportage, p. 35; J. Jansen van Galen en H. Spiering, Rare jaren. Nederland en de Haagse Post 1914-1990, Amsterdam I993, p. 252-253 en 280-28I.

35. J. Niemöller, 'New Journalism en de Haagse Post', Pafionate. Tijdschrift voor de nieuwe letteren, 9, 6, nov./dec. 2002, p. 15-18.

36. Bestudeerd zijn de jaargangen I970, 1973, 1976, 1979 en 1982 .

37. Haagse Post (H P) I maart I975, p. 32-35; H P I3 november I976, p. 67-70; н P 20 maart I976, p. $45-48$.

38. Jansen van Galen en Spiering, Rarejaren, p. 252-253; Johnson, The New Journalism, p. 96.

39. Hр I maart I975, p. 32-35.

40. Hр 4 november I970, p. 20-2I; H P I6 december I970, p. 52-64.

4I. Jansen van Galen en Spiering, Rare jaren, p. 2IO-2II, 2I3, 239 en 252-253; Bibeb, 'Cherry Duyns' in: Idem, Een grote hartstocht moet je volgen, Amsterdam I993, p. 225-238, aldaar p. 23I.

42. Van den Broek, Heimwee naar de politiek, p. I25.

43. Jansen van Galen en Spiering, Rare jaren, p. 2I8-2I9.

44. Hр 4 november I970, p. 54-60; н P II november I970, p. 50-67; н Р 2 december I970, p. 46-59.

45. Jansen van Galen en Spiering, Rare jaren, p. 213, 222-223, 239 en 24I; Van den Broek, Heimwee naar de politiek, p. I34.

46. Hp 20 oktober I973, p. I4-I7.

47. Jansen van Galen en Spiering, Rare jaren, p. 24I-242 en 252-253; н P 7 februari I976, p. 6-8 en io februari I979, p. 34-4I.

48. Jansen van Galen en Spiering, Rare jaren, p. 274; н р 6 september 1975 en 23 oktober I976; H P I2 november I983; н P I4 februari I976, p. I0-I5; zie ook: J. van Aschs, Het bal der eenzamen. Reportages, Amsterdam I992.

49. Нр го januari I976, p. 24-27; н р I7 april І976, p. I6-г9; н р 2І augustus I976, p. 6-9.

50. Нр 5 mei I979; нр 4 september I982, p. 23-54.

5I. Zie de jaargangen I98I en I984.

52. Weber, The reporter as artist, p. II7.

53. Bestudeerd zijn: Bibeb in Holland, Utrecht I958; Bibeb en VIP's, Amsterdam I965; Bibeb en andere VIP's, Amsterdam I967; Bibeb interviews 73-77, Amsterdam 1977; Bibeb met... Interviews, Amsterdam I980; Een grote hartstocht moet je volgen, Amsterdam I993.

54. Van den Broek, Heimwee naar de politiek, p. I33-I34.

55. Ischa Meijer, Interviewen voor beginners, Utrecht I987, p. 8.

56. Hр 28 oktober I970, p. 86-9I.

57. Meijer, Interviewen, p. IO-II.

58. Bibeb, 'Cherry Duyns', p. 23I; н P I3 november I976, p. 67-70; H.J.A. Hofland, 'Het slop van de journalistiek', in: H.J.A. Hofland, H. Keller en H. Verhagen, Vastberaden maar soepel en met mate. Herinneringen aan Nederland 1938-1948, Amsterdam I976, p. I5-23, aldaar p. I5.

59. C. Vos, 'Een onverschillige geschiedenis?', Jaarboek Mediageschiedenis, 5, I993, p. 227-260, aldaar p. 229-232, 238, 247-250 en 255 . 